\title{
UKRAINE'S INVESTMENT ATTRACTIVENESS ON THE WORLD STAGE DURING THE COVID-19 PANDEMIC
}

\section{Tetiana Ripa ${ }^{1}$}

DOI: https://doi.org/10.30525/978-9934-26-077-3-34

Abstract. In the current economic conditions and increased competition, the ability of an entity to attract investments, i.e., its investment attractiveness, becomes important. It largely depends on the stability of the external and internal environment, the efficiency of economic activity, the priority of tasks, etc. The needs of modern society are growing rapidly; therefore, it is necessary to carry out the economic development of the country at the same time. Assessing the development of the investment market is the basis for a comprehensive approach to the analysis of the investment attractiveness of economic entities. The investment market is the area of investment objects in all its forms, taking into account the conditions of investment activity at certain stages of economic development of an enterprise, the economy, the region, and the country as a whole. The article considers the main indicators that characterize the economic development of Ukraine. The subject of the study is the main indicators that characterize the investment attractiveness of the country. The purpose of the study is to analyze the dynamics of the level of investment attractiveness of Ukraine during 2010-2020 in the context of the COVID-19 pandemic. The research is based on scientific methods, among which it is expedient to distinguish: analysis and synthesis, comparison, idealization and abstraction, as well as systematization and generalization - when formulating conclusions as a result of the study. As a result, the dynamics of the gross domestic product, the index of investment attractiveness are analyzed. The change in the number of business entities in Ukraine over the past decade has shown a negative trend. It is found out that the structural sector in Ukraine is wholesale and retail trade. The dynamics of the volume of retail trade turnover of Ukraine during

\footnotetext{
${ }^{1}$ Ph.D. in Economics,

Senior Lecturer at the Department of Economics and Finance of the Enterprise, Kyiv National University of Trade and Economics, Ukraine
} 
2010-2020 and the index of the physical volume of retail trade turnover of Ukraine are determined. The method of assessing the level of investment attractiveness of the country is considered. The importance of the ability to create new competitive advantages and keep the existing ones under the influence of various factors has been proved. Ukraine's ranking positions in comparison with other countries of the world in terms of gross domestic product, index of business conditions, index of economic freedom, index of global competitiveness, world competitiveness and world digital competitiveness are also determined. The investment environment during 2020 was negatively assessed by entrepreneurs and investors. It turned out that $78 \%$ of surveyed company executives consider the current investment climate unfavorable, only $12 \%$ consider Ukraine a profitable market for new investors. At the same time, among the negative factors influencing the investment climate, there was chosen a weak judiciary, high levels of corruption and the shadow economy. As a result of the analysis of the dynamics of these indicators, negative trends were revealed due to the aggravation of economic crises, hostilities in the east, the annexation of the Autonomous Republic of Crimea, destabilization of social and political life, COVID-19 pandemic. There is a deterioration of rating places on these indicators, which requires the immediate development of new regulations, the choice of a new strategy for attracting investment, as well as the effective use of levers of influence on the country's economy.

\section{Introduction}

In the conditions of deepening transformational processes of development and formation of market relations in the system of world economy all branches of the economy of Ukraine undergo significant transformations and reorientation.

Under the influence of internal and external factors, the market environment is changing. Despite great resource potential, Ukraine fails to gain leadership positions compared to economically developed countries. Therefore, it is advisable to study the current state of Ukraine's economy, analyze the dynamics of key indicators, assess the place in the world economy and find possible ways to improve the situation.

The concept of «investment attractiveness» is widely used in science. It has its own specifics depending on the object that carries this characteristic. 
In order to determine the position of Ukraine in the world economy, it is advisable to study its investment attractiveness at different levels, as well as to compare it with other countries.

The relevance of the study of the investment attractiveness of Ukraine is due to the growth of economic processes, the effects of economic crises, and the global pandemic COVID-19 determine the need to manage its level to expand markets and spheres of influence to attract foreign investment. The high level of investment attractiveness of the country is the key to its stable economic development.

The purpose of the study is to analyze the dynamics of the level of investment attractiveness of Ukraine during 2010-2020 during the COVID-19 pandemic.

The research is based on scientific methods, among which it is expedient to distinguish: analysis and synthesis, comparison, idealization and abstraction, as well as systematization and generalization - when formulating conclusions as a result of the study.

The following domestic and foreign scientists were engaged in problems on this issue and its research at different levels: Bandurin F., Berestovy K., Blank I., Bocharov V., Haidutsky F., Hutkevych S., Ivanov Yu., Kopul O., Korenyuk P., Mazaraki A., Nosova O., Pidlisetsky H., Epstein D. and many others.

Despite thorough research of theoretical and methodological principles, the effective use of rating indicators of economic development of countries in the management system remains logically incomplete.

\section{Economic development of Ukraine in 2010-2020}

In modern business conditions and the intensification of competition, the ability of an entity to attract investment, ie its investment attractiveness, becomes important. It largely depends on the stability of the external and internal environment, the efficiency of economic activity, the priority of tasks and so on. The needs of modern society are growing rapidly; therefore, it is necessary to carry out the economic development of the country at the same time.

Statistics show that Ukraine does not occupy the best position in the world economy. In this regard, it is advisable to analyze the dynamics of the country's development during 2010-2020, consider the main trends and identify possible causes of this problem. 
It is advisable to start with a study of trends in the gross domestic product of Ukraine.

Figure 1 presents the dynamics of change in the volume of the gross domestic product of Ukraine for 2010-2020 as a percentage of the corresponding quarter of the previous year. Data for 2010 are presented in constant prices of 2007, and for 2011-2020 - in constant prices of 2010 without taking into account the temporarily occupied territory of the Autonomous Republic of Crimea, the city of Sevastopol and part of the anti-terrorist operation zone.

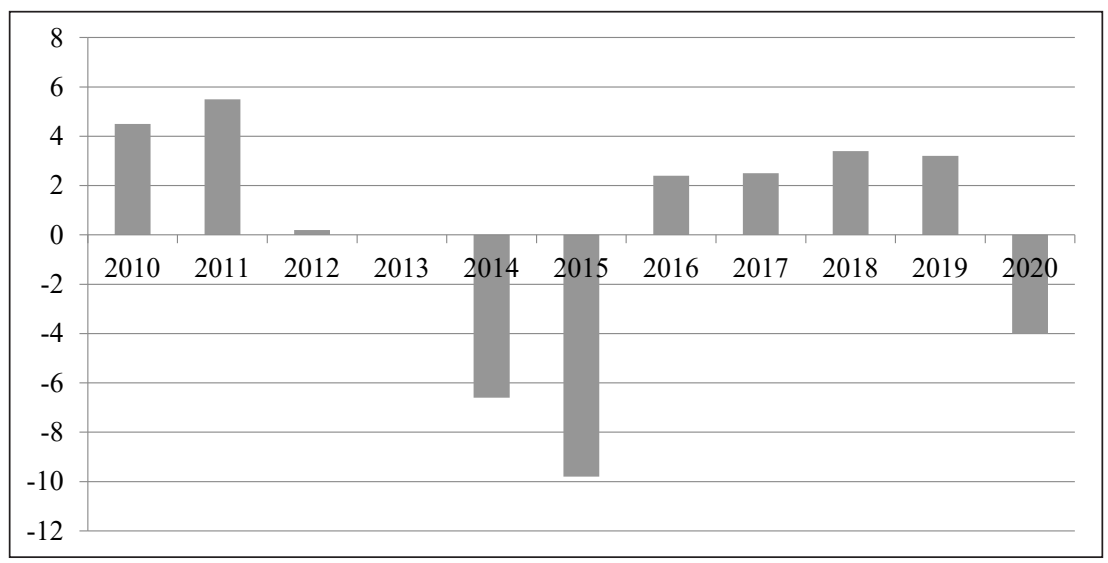

Figure 1. Dynamics of change in the volume of the Gross Domestic Product of Ukraine during 2010-2020, as a percentage, at constant prices of 2010 and 2016

Source: developed on the basis of data from the State Statistics Service of Ukraine [1]

The next stage of the study is the analysis of the dynamics of income and expenditure of the population of Ukraine during 2010-2020. Detailed dynamics of incomes and expenditures of the population of Ukraine during 2007-2016 confirms the positive trend of proportional growth of indicators, which shows their stability and balance. However, we can not ignore the inflationary processes in Ukraine, the crisis and the insufficient growth rate of these indicators in the current economic environment, due to which, the rate of change in income is quite low. 
It is also advisable to study the dynamics of the number of economic entities in Ukraine during 2010-2019 to determine which sector of the economy is structural in order to further influence it and adjust Ukraine's position in the world economy (Figure 2).

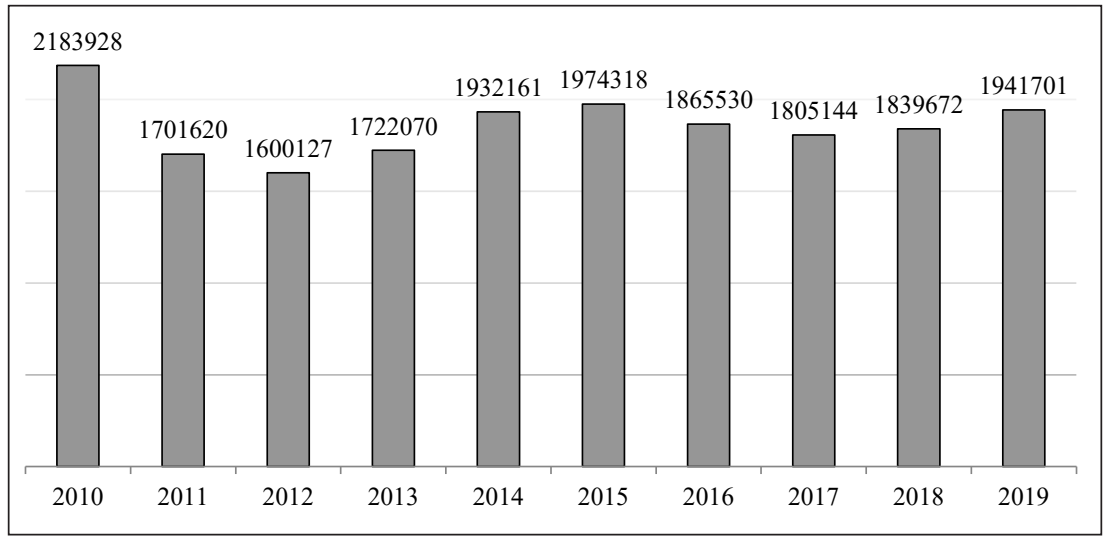

Figure 2. Dynamics of change in the number of business entities of Ukraine during 2010-2019

Source: developed on the basis of data from the State Statistics Service of Ukraine [1]

The presented information indicates a decrease in the number of business entities in Ukraine during the study period. The largest number was recorded in 2010 and amounted to 2183928 subjects. Since 2014, there has been a gradual decrease in the number of business entities and only since 2018 the situation has improved. Such dynamics is due to the crisis of the economy and the increase in the number of bankrupt enterprises. Based on statistics, it is found out that bankruptcy is one of the biggest problems of the domestic economy.

We have determined that the structural sector of the domestic economy is retail and wholesale. At the present stage of development in the total number of economic entities of Ukraine, this sector accounts for the largest share.

According to the State Statistics Service of Ukraine [1], in 2019 the number of business entities was 1941,701 units. The share of retail and wholesale enterprises is $46.9 \%$ (834159 units). Despite the constant 
reduction in the number of economic entities in Ukraine, the number of enterprises engaged in wholesale and retail trade is increasing every year. This indicates the transformation processes in the domestic economy and the realization of the market environment.

We propose to pay more attention to the activities of trade enterprises. Consider the statistics on the dynamics of retail trade, which includes the retail turnover of enterprises (legal entities) engaged in retail trade, and estimated data on sales of goods in the markets and individual entrepreneurs (Figure 3).

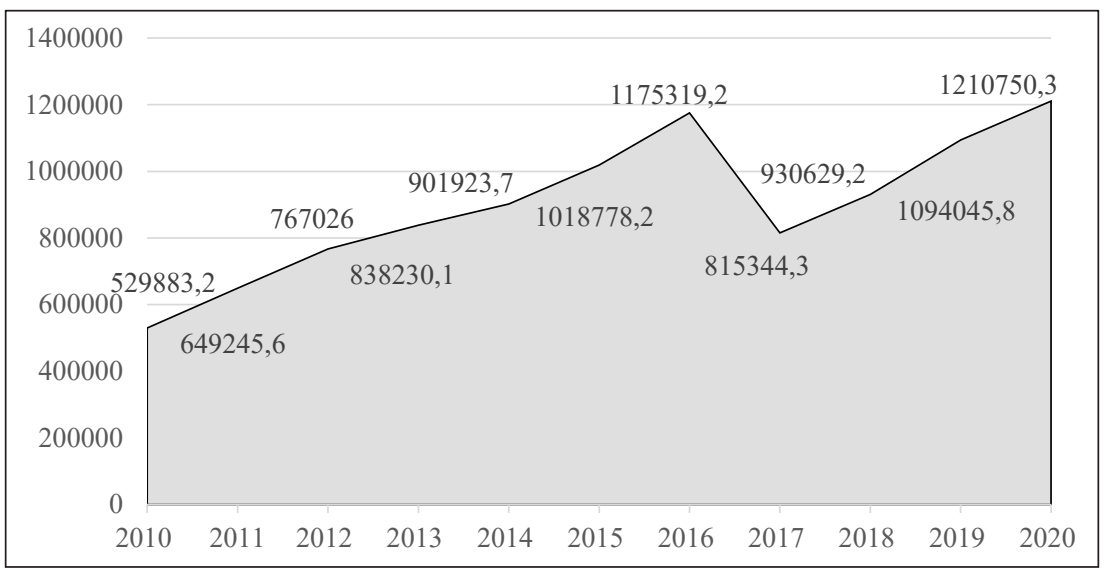

Figure 3. Dynamics of retail trade turnover in Ukraine during 2010-2020, UAH million

Source: developed on the basis of data from the State Statistics Service of Ukraine [1]

It would seem that all is well, the retail trade turnover is growing every year (except for a sharp decline in 2017 to 815344.3 million UAH, from 1175319.2 million UAH in 2016).

However, the dynamics of the index of the physical volume of retail trade turnover indicates a negative trend (Figure 4).

According to the analysis of data on the structure of retail trade turnover of retail trade enterprises in 2010-2020, it is expedient to distinguish food and non-food products from among product groups. Among them, the share of non-food products is higher throughout the analyzed period (Figure 5). 


\section{Tetiana Ripa}

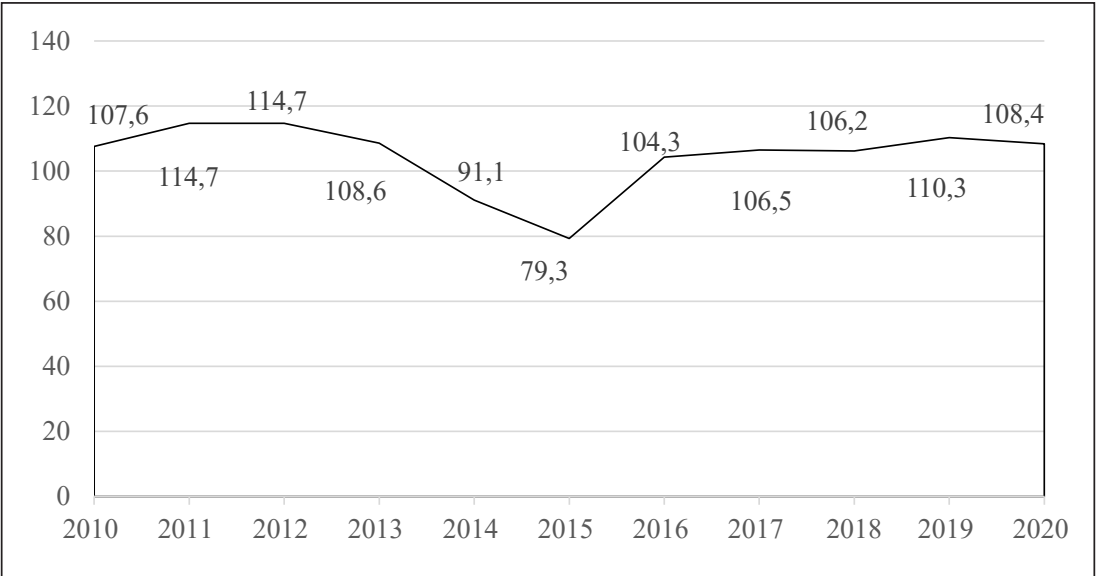

Figure 4. Dynamics of the index of physical volume of retail trade turnover of Ukraine to the corresponding period of the previous year during 2010-2020, as a percentage

Source: developed on the basis of data from the State Statistics Service of Ukraine [1]

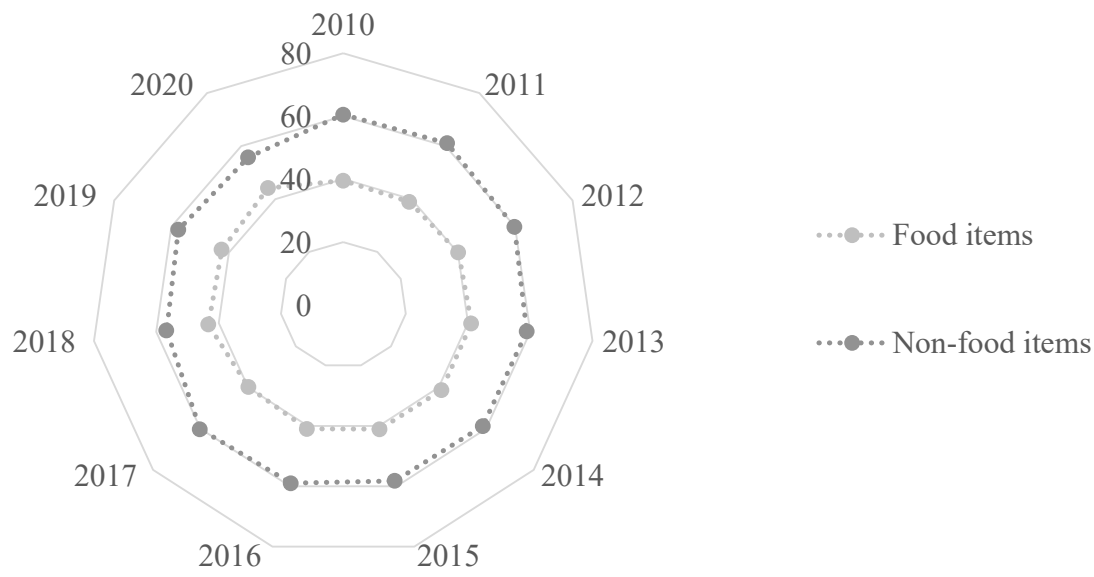

Figure 5. Share of commodity groups of retail trade turnover of retail trade enterprises in 2010-2020, as a percentage

Source: developed on the basis of data from the State Statistics Service of Ukraine [1] 
Thus, in the course of the research, we found that the largest share in the structure of the total number of business entities of Ukraine is occupied by trade enterprises. Therefore, it is expedient to direct reforms to it in order to achieve the maximum effect reflected in the indicators of the characteristics of Ukraine's position in the world economy.

The analysis of statistical information in general shows transformational shifts, however, in the conditions of the pandemic the positive dynamics either has an insignificant level, or is absent at all.

\section{Basics of the formation of investment attractiveness of the country}

Assessment of investment market development is the basis for a comprehensive approach to the analysis of investment attractiveness of economic entities. The investment market is the area of investment objects in all its forms, taking into account the conditions of investment activity at certain stages of economic development of the enterprise, the economy, the region and the country as a whole (Figure 6).

\begin{tabular}{|l|}
\hline Investment attractiveness of Ukraine \\
\hline \hline Investment attractiveness of economic sectors \\
\hline \hline Investment attractiveness of the region \\
\hline \hline Investment attractiveness of an enterprise \\
\hline
\end{tabular}

\section{Figure 6. Hierarchical levels of investment attractiveness}

There are different approaches and methods for assessing investment attractiveness, but all of them can be divided into three main groups [2, p. 60]:

1. Statistical approach. It is based on the analysis of statistical data on the inflow of investments into the country's economy. This approach is based on the assumption that high statistics are the basis for the high investment attractiveness of the economy. The disadvantage of this approach is the inability to take into account all the factors that investors pay attention to. At the same time, this approach is formalized and based on specific socioeconomic indicators.

2. Method of expert assessments. Using this method, the expert provides his own assessment of the significance of indicators, ie selects the most 
important, after which the analysis of these indicators in the dynamics is carried out and conclusions about the investment attractiveness of the region are drawn. This approach is very often reflected in foreign investment practice and assessment of investment attractiveness. The main advantage of the expert approach is the ability to adapt to the needs of specific investors indicators and factors that are studied, as well as the ability to conduct an in-depth analysis of the attractiveness of certain sectors of the economy. At the same time, the significant shortcomings of the application of the method of expert evaluations include the subjectivity of the evaluation and the dependence of the conclusions on the positions of an expert.

3. Rating approach. When assessing the investment attractiveness of the national economy, we can distinguish two types of this approach - ratinganalytical and rating approaches based on surveys. The most widely used is the rating-analytical approach, which consists of the analysis of existing indicators of investment attractiveness, their grouping and the formation of an integrated indicator. This approach is easy to use and easy to interpret the results of the study and is effective for analyzing investment attractiveness at the macro level. A significant disadvantage is the difficult choice of the correct method of calculating the indicators that will be taken into account during the analysis. The rating approach based on surveys is based on a survey of experts in the region, as a result of which an overall rating is formed. This approach is often used by the world's leading consulting and analytical agencies.

Today, there is still no single methodology for assessing the investment attractiveness of the country's economy, which would be based on the assessment of economic, social, political, regulatory and other factors of influence. Therefore, to assess the investment attractiveness one needs to use several methods in combination [2, p. 62].

To assess the investment attractiveness of industries, I. Blank proposed an integrated indicator calculated by summing the products of the rank value of each synthetic indicator on its significance (as a percentage) in making investment decisions [3, p. 86]. The Central Institute of Economics and Mathematics (CEMI) has developed a method for assessing the investment attractiveness of the industry, which is based on indicators of return on assets used, industry development, its importance for the needs of the economy [4, p. 128-129]. 
To assess the investment attractiveness of the region, the World Bank proposes to use four main indicators: the size of the gross regional product and fixed assets per capita, the characteristics of natural and human resources. The high investment attractiveness of the region allows attracting large investments for its development and guarantees profits for investors. The investment attractiveness of the region can be determined by: favorable geographical location of the region, the availability of the necessary natural resources, cheap and skilled labor, developed infrastructure, market [5, p. 12].

$\mathrm{S}$. Hutkevych proposed to use five groups of indicators to assess the investment attractiveness of the regions: 1) assessment of the economic development of the region; 2) assessment of the level of investment infrastructure development; 3) assessments of the demographic characteristics of the region; 4) assessment of the level of development of market relations and infrastructure; 5) investment risk assessment [6, p. 44].

To assess the investment attractiveness of the regions, O. Stalinska proposes to use the matrix method and the following indicators: population; production growth; investment development; financial results; export; payables; wage level; wage arrears [7, p. 68-69].

For each of these indicators, it is proposed to calculate specific, minimum, maximum, normalized and reference values. By comparing these values of indicators, the level of investment attractiveness of a region relative to other regions is determined.

To assess the investment attractiveness of enterprises, it is important to identify their potential financial, production, organizational and other benefits that are of most interest to investors. Yu. Ivanov made a corresponding generalization of such methods and proposed to divide them into six groups to determine the investment attractiveness of enterprises: methods based on the analysis of comparative advantages; methods based on the theory of equilibrium of the enterprise and industry; methods based on the theory of effective competition; methods based on the theory of product quality; matrix methods of competitiveness assessment; integrated method [8, p. 47-48].

In practice, it is known that investors are more willing to entrust their financial resources to transparent businesses. Thus, more than $80 \%$ of foreign direct investment in Ukraine is share capital, namely joint-stock companies belong to business entities that most fully disclose information about their financial condition compared to other forms of business organization. 
In the current difficult socio-economic conditions, analysts do not give a positive assessment of the level of investment attractiveness of Ukraine. Diagnosing the state of investment attractiveness, they pay attention to the index of investment attractiveness of Ukraine.

Therefore, it is necessary to study the trends of change in the index of investment attractiveness of Ukraine during 2009-2017 (Figure 7).

The index of investment attractiveness is measured on a 5-point Likert scale, conditionally positive is a value greater than 3 . According to the European Business Association, only for 4 years during the last decade, the index of investment attractiveness of Ukraine exceeded 3 (2010, 2011, 2017 and 2018). The stable unsatisfactory value of the indicator has already become the norm for the country.

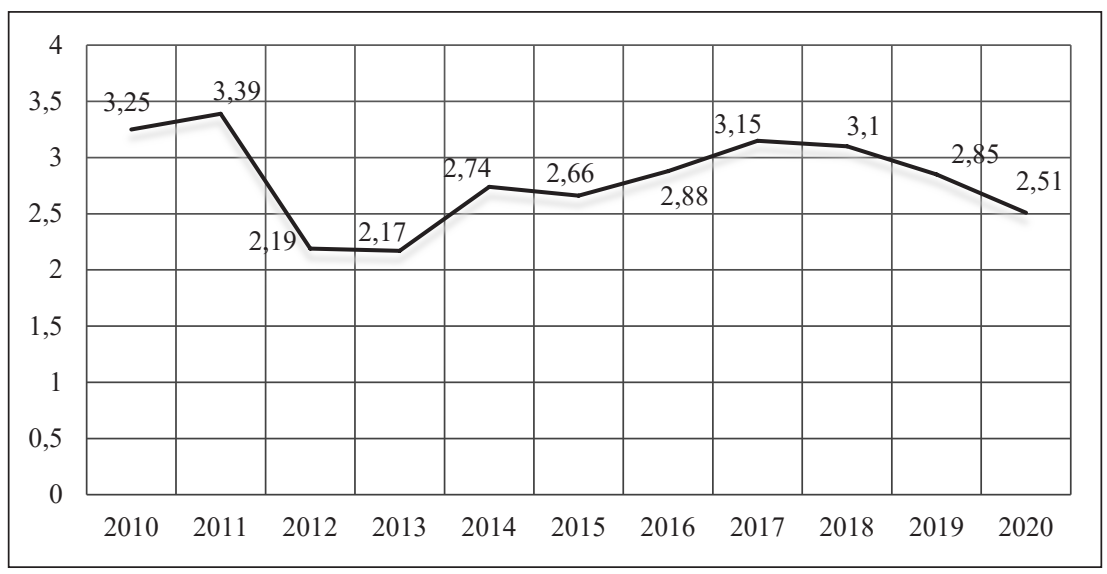

Figure 7. Dynamics of the index of investment attractiveness of Ukraine by target direction during 2010-2020

Source: developed on the basis of data from the European Business Association [9]

In 2020, the European Business Association conducted a survey by interviewing company executives. A number of issues were proposed, including:

- How do you assess the investment climate in Ukraine?

- How do you assess the current investment climate for your company compared to the previous 6 months? 
- What are your forecasts for the investment climate in the next 6 months?

- Will it be profitable to invest in Ukraine in the next 6 months?

- What are your expectations for doing business in your sector in the next 6 months?

The investment climate during 2020 was negatively assessed by entrepreneurs and investors. It turned out that $78 \%$ of respondents consider the current investment climate unfavorable, only $12 \%$ consider Ukraine a profitable market for new investors. At the same time, among the negative factors influencing the investment climate, a weak judicial system $(94 \%$ of respondents), a high level of corruption (91\% of respondents) and the shadow economy ( $75 \%$ of respondents) were chosen.

The investment climate has been affected by the pandemic as well. The results of the policy of attracting foreign direct investment (FDI) in 2020 proved to be a failure - the increase in FDI inflows to Ukraine during 2020 was negative. This means that investors did not enter, but instead withdrew investment resources. This withdrawal amounted to $\$ 400$ million [10].

This was partly due to the coronavirus crisis, as a result of which we are seeing a reduction in FDI worldwide. But more important is the fact that Ukraine has failed to offer international investors the appropriate business and safety conditions.

The advertised so-called «investment nanny», under which individual investors would be given special conditions, did not interest (and probably will not interest even after the adoption of the law) any serious investor, since, firstly, it seems that the proposed preferential terms will be used first for lobbying purposes, and secondly - for them (domestic and international investors), the rule of law, low corruption, ensuring property rights are more important. And the next activity around dubious tax changes has put «on pause» the decision on FDI to Ukraine [11].

At the same time, Ukraine attracts investors with such positive facts and changes as: simplification of customs procedures and positive changes for international companies in the oil and gas industry and IT business.

\section{Ukraine's place in the world economy}

Today, the world economy continues to recover from the worst crisis since World War II. However, it faces new challenges - a global pandemic. In such conditions, clear steps on the part of the government are of particular 
importance - the introduction of a number of reforms, the formation of a new regulatory framework and effective governance in all sectors of the economy due to the imposed restrictions.

The study considers the main indicators of the characteristics of the current state of Ukraine's economy, analyzes their dynamics over the past decade, and identifies the causes of destabilization and possible ways to improve. However, to assess competitiveness, it is necessary to compare the state of Ukraine's economy with other countries. Therefore, it is very important to consider its position in the ranking lists on a number of indicators.

One of the most accurate ways to assess the economic development of any state is to determine the gross domestic product per capita.

Gross Domestic Product - is the total value of all final goods and services produced during the year in a country by its residents, expressed in final consumer prices.

According to the State Statistics Service of Ukraine, in 2020 the real gross domestic product of Ukraine decreased by $4 \%$. The area of temporary accommodation and catering has suffered the most (-28,5\%). Ukraine's economy has shrunk so rapidly for the first time since $2015(9,8 \%)$. At the same time, in 2021 the World Bank expects the Ukrainian economy to grow by $1.5 \%$. And countries such as China, Japan, Germany, Great Britain, France, India, Italy, Brazil, and Canada managed to hold the leading positions.

Also in need of attention is the Gross National Income per capita - the total value of all goods and services produced during the year in a given country, as well as income received by citizens and organizations from abroad, less income exported from the country by non-residents. It is also one of the key indicators of economic development. The World Bank methodology provides for the division of countries into three categories depending on the volume of this indicator:

1. Countries with a high level of per capita income (more than 12616 dollars).

2. Countries with an average per capita income (1036-12615 dollars).

3. Countries with a low per capita income (less than 1035 dollars).

Ukraine ranked second in the ranking of countries in terms of Gross National Income per capita. Leading positions were maintained by the 
following countries and regions: Monaco, Liechtenstein, the Norman Islands, Bermuda, the Isle of Man, Norway, Switzerland, Gibraltar, Luxembourg, and Qatar.

The World Bank also presented a ranking of countries according to the Doing Business Index. In 2013, Ukraine ranked 152nd, however, in 2020 it rose to 64 th position (Figure 8).

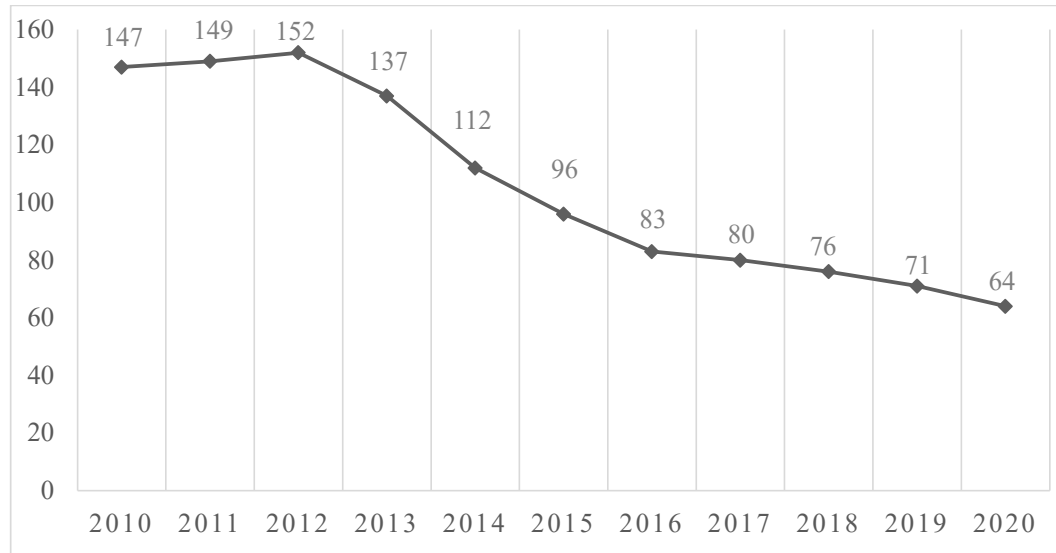

Figure 8. Dynamics of the Doing Business Index of Ukraine during 2010-2020

Source: developed on the basis of World Bank data [12]

With an increase in the overall rating by 7 positions, Ukraine has shown growth in five areas [13]:

- investor protection - protection of minority investors has been strengthened by introducing a requirement for more detailed disclosure of information about transactions with interested parties;

- obtaining building permits - the process of obtaining building permits was simplified, by eliminating the requirement to hire an external observer and introducing an online notification system, and also the cost of obtaining building permit was reduced by reducing the contribution to the Kyiv City Council;

- connection to the power grid - the process of obtaining electricity was simplified by optimizing the production of technical conditions and 
introduction the geographic information system, reliability of energy supply was increased by introducing a compensation mechanism for disconnection;

- international trade - the import time was reduced due to simplification of requirements for certification of conformity for auto parts;

- property registration - property registration was simplified by increasing the transparency of the land management system.

The next socio-economic index is the Index of Economic Freedom. The following indicators are used to calculate it: property rights; freedom from corruption; fiscal freedom; government participation; freedom of enterprise; freedom of labor; monetary freedom; freedom of trade; freedom of investment; financial freedom.

Figure 9 presents information on changes in the index of economic freedom during 2010-2019.

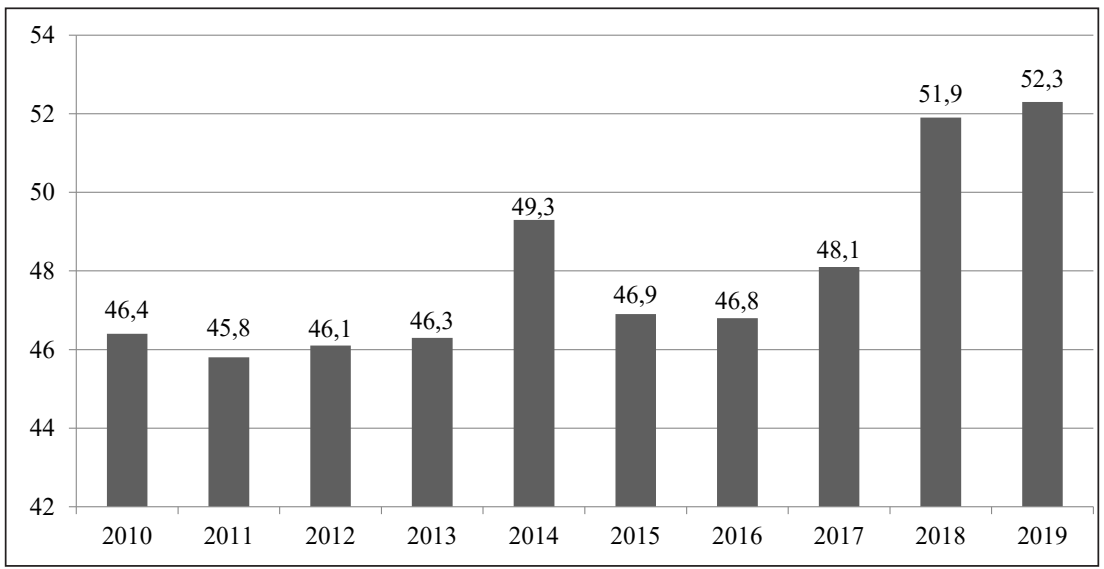

Figure 9. Dynamics of the Index of Economic Freedom of Ukraine during 2010-2019

According to the index, in 2019 Ukraine ranked 147th out of 186 countries, which is the best position in the last decade (Figure 10).

Given the low ratings of Ukraine in the field of investment attractiveness and business regulation, full information openness, the readiness of business entities to provide complete and reliable data on the financial condition can convince investors to direct their financial resources to cover the needs of attracted capital. 


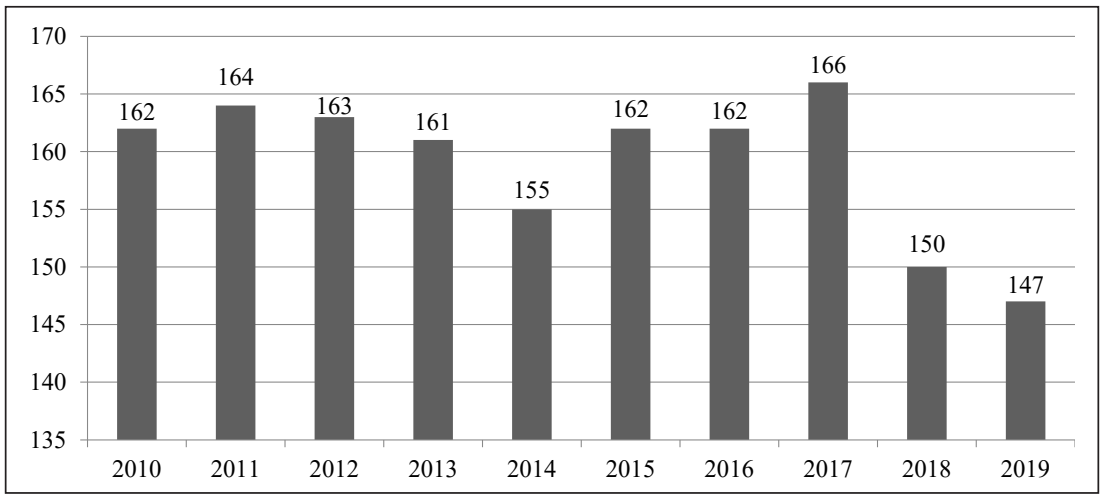

Figure 10. Ukraine's position in the world ranking according to the index of Index of Economic Freedom during 2010-2019

We have studied the features of the calculation of the Global Competitiveness Index, so we should dwell on the position of Ukraine in the ranking according to this indicator.

Ukraine continues to lose its position in the world rankings every year. Thus, according to the World Economic Forum on the Global Competitiveness Index in 2018-2019, Ukraine ranked 85th among 138 countries, losing 5 positions in the year (Figure 11).

The leading positions in the ranking of countries in the Global Competitiveness Index were held by the following countries: Switzerland, Singapore, USA, Netherlands, Germany, Sweden, Great Britain, Japan, Hong Kong, and Finland.

According to the World Economic Forum, Ukraine has worsened its position in 7 of the 12 key indicators used to calculate the Global Competitiveness Index. We lost the most (17 points) on the component «Labor market efficiency», as well as 9 points on indicators that characterize the development of the country's financial market and health care and primary education. This is a negative trend due to fluctuations in the domestic environment and macroeconomic destabilization.

Related is a study by the Swiss Institute for Management Development (IMD), which ranks 63 countries in the world: World Competitiveness and World Digital Competitiveness. The country's greatest achievement 
was 49th place in 2013 and 2014, but in the next five years, the situation worsened, and only in 2019 Ukraine took 54th place, rising in the ranking by five positions. Among the factors that reduce Ukraine's place in the ranking, experts name the inefficiency of the government.

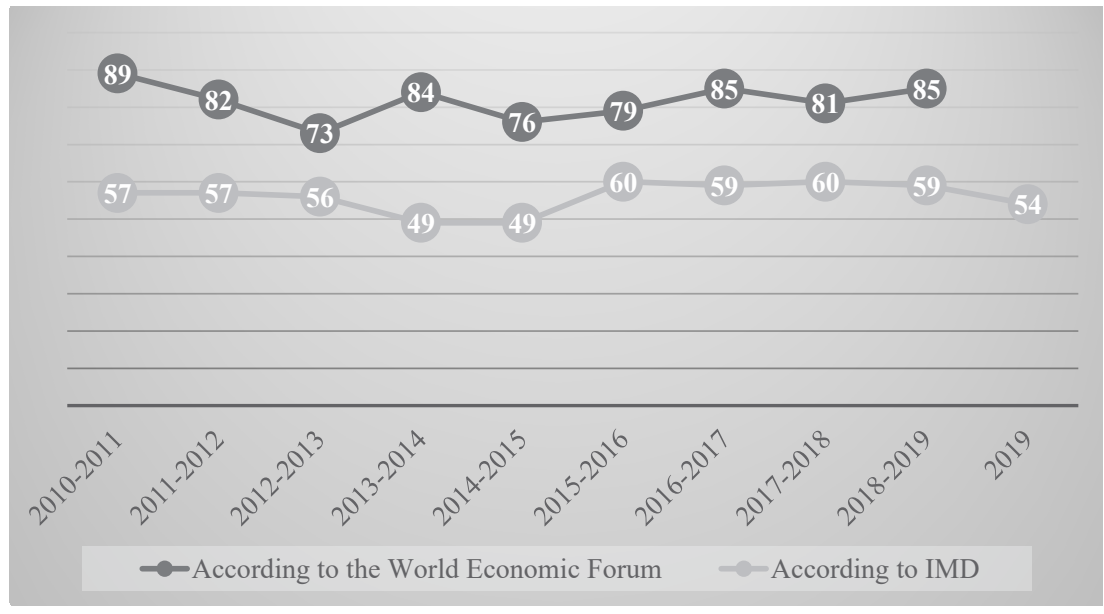

Figure 11. Rating positions of Ukraine according to the Global Competitiveness Index during 2010-2019

Source: developed on the basis of data from the World Economic Forum [14; 15]

The Digital Competitiveness Index assesses the ability of countries to implement and study technologies that contribute to the transformation of government, business models, and society as a whole (Figure 12).

In the dynamics, there is a very negative trend to reduce the country's place in all, without exception, ranking positions.

The Digital Competitiveness Index of Ukraine in 2019 was 55,255, moving to the 60th place in the ranking, with the largest gaps in the development of science and education, according to researchers. Subindicators had a decisive influence on the formation of the rating. Indicator «knowledge» - the 40th place, including sub-indicators: «ability» - the 57th; «training and education» - the 21st; «scientific concentration» the 41st place. Indicator «technology» - the 61st place, including subindicators: «regulation» - the 54th; «capital» - the 62nd; «technology 
development» - 60's. Indicator «future readiness» - the 61st place, including sub-indicators: «adaptability» - the 59th; «business activity»the 45 th; «IT integration» - the 61st place.

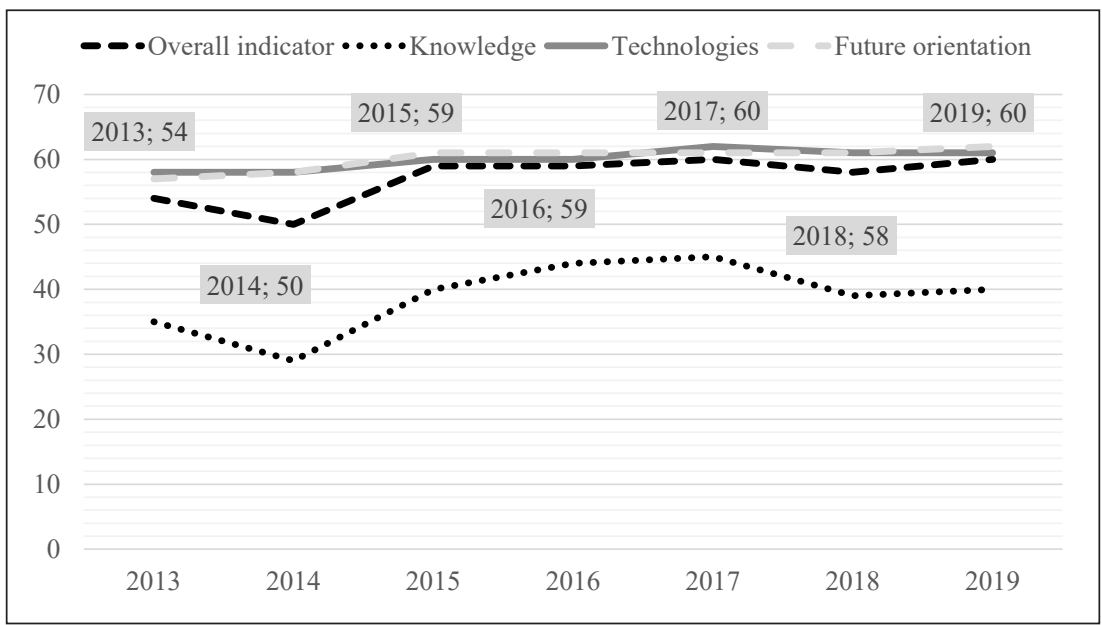

\section{Figure 12. Rating positions of Ukraine according to the Digital Competitiveness Index during 2013-2019}

Thus, as a result of the study, we analyzed the dynamics of a number of indicators that characterize the economic development of Ukraine and identified its ranking positions along with other countries.

\section{Conclusions}

As a result of the study, the main indicators characterizing the economic development of Ukraine during 2010-2020 were considered. Among them, a special place is occupied by the gross domestic product, the index of global competitiveness, the index of investment attractiveness. As a result of the analysis of the dynamics of these indicators, negative trends were revealed due to the aggravation of economic crises, hostilities in the east, the annexation of the Autonomous Republic of Crimea, destabilization of social and political life, COVID-19 pandemic.

The reduction in the number of business entities in Ukraine over the last decade is a negative trend. It is determined that the main reason for 
this situation is the bankruptcy of domestic enterprises due to low levels of competitiveness and the inability to adapt to changing external and internal conditions and attract investments.

It is established that the structural sector in Ukraine is wholesale and retail trade. Therefore, we recommend that the government's reform activities be directed at it.

The study proposed methodological approaches to assessing the level of investment attractiveness of the country and proved the importance of the ability not only to create new competitive advantages but also to keep the existing ones under the influence of factors; Ukraine's ranking positions in comparison with other countries of the world in terms of gross domestic product, index of business conditions, index of economic freedom, index of global competitiveness, global competitiveness and world digital competitiveness are determined. Deterioration of rating places according to these indicators has been found, which requires immediate development of new regulatory and legal support, selection of a new strategy for attracting investments, as well as effective use of levers of influence on the country's economy.

\section{References:}

1. State Statistics Service of Ukraine. URL: http://www.ukrstat.gov.ua/

2. Korenyuk P., Kopyl O. (2018) Kontseptualni pidkhody ta metody vyznachennia investytsiinoi pryvablyvosti natsionalnoi ekonomiky [Conceptual approaches and methods for determining the investment attractiveness of the national economy]. Economic Journal of the Lesya Ukrainka East European National University. SECTION II. Economics and management of the national economy, no. 2, pp. 56-62.

3. Blank I.A. (2009) Finansovyi menedzhment [Financial management]. Kyiv: Elga. (in Ukrainian)

4. Nosova O.V. (2003) Otsinka investytsiinoi pryvablyvosti Ukrainy: osnovni pidkhody [Assessment of the investment attractiveness of Ukraine: basic approaches]. Economics and forecasting, no. 3, pp. 119-137.

5. Alymov A.N., Emchenko V.N. (2001) Konkurentospromozhnist natsionalnoyi ekonomiky [Competitiveness of the national economy]. Working paper, Kyiv: NAS of Ukraine. Inst. of Economics. (in Ukrainian)

6. Hutkevych S.A. (2003) Investytsiyna pryvablyvist agrarnogo sektoru ekonomiky [Investment attractiveness of the agricultural sector of the economy]. Kyiv: Publishing house of the European university. (in Ukrainian)

7. Onikiienko S. (2001) Oblikovi metody otsinky investytsiinoi pryvablyvosti [Accounting methods for assessing investment attractiveness]. Bulletin of the National bank of Ukraine, no. 7, pp. 49-51. 
8. Ivanov Yu.B. (1997) Konkurentospromozhmist pidpryemstva v umovakh formuvannya rynkovoyi ekonomiky [Competitiveness of the enterprise in the conditions of the formation of a market economy]. Kharkiv: KhGEU. (in Ukrainian)

9. European Business Association. URL: https://eba.com.ua/

10. Foreign direct investment from 2002 to 2020. URL: https://bankchart.com.ua/ spravochniki/indikatory_rynka/foreign_direct_investment

11. Razumkov Center. Ukraine 2020-2021: unjustified expectations, unexpected challenges (analytical assessments). URL: https://razumkov.org.ua/uploads/ other/2021-PIDSUMKI-PROGNOZI-UKR-ENG.pdf

12. World Bank. URL: http://www.worldbank.org/uk/country/ukraine

13. Ukraine's place in the World Bank's "Doing Business" rating. Analytical review. URL: https://www.me.gov.ua/Documents/Detail?lang=ukUA\&id $=9 c d 60 d 26-f a 44-481 c-b b 2 a-1 b 28 c 713081 \mathrm{f} \&$ title=AnalitichniiOgliadmists eUkrainiUReitinguSvitovogoBankudoingBusiness\&isSpecial=true

14. The Global Competitiveness (2019). Report. URL: http://www3.weforum.org/ docs/WEF TheGlobalCompetitivenessReport2019.pdf

15. IMD Global Competitiveness Rating. Humanitarian portal (2019). Report. URL: https://gtmarket.ru/ratings/the-imd-world-competitiveness-yearbook (accessed 04 April 2021). 